\title{
HUBUNGAN ASUPAN PURIN, VITAMIN C DAN AKTIVITAS FISIK TERHADAP KADAR ASAM URAT PADA REMAJA LAKI-LAKI
}

\author{
Siti Santiaji Pursriningsih, Binar Panunggal ${ }^{*}$ \\ Program Studi Ilmu Gizi Fakultas Kedokteran Universitas Diponegoro \\ J1.Dr.Sutomo No.18, Semarang, Telp (024) 8453708, Email : gizifk@undip.ac.id
}

\begin{abstract}
Background : Hyperuricemia is a condition that uric acid levels in blood above the normal value. Uric acid levels are influenced by intake of purine, intake of vitamin $C$ and strenuous physical activity. The purpose of this study was to determine the correlation between intake of purine, vitamin $C$ intake, physical activity and uric acid levels in boys adolescent.

Methods : This research was observational study with cros sectional design. Subject were 66 boys adolescent (1618 years old) in SMAN 2 Slawi. Subject was selected by simple random sampling. Data include the characteristics of subject, purine and vitamin $C$ intake, physical activity and uric acid levels. Purine and vitamin $C$ intake was obtained using Semi Food Frequency Quantitative and physical activity by a 3 days Quessionaire Physical activity. Enzymatics PAP uricase method was used to analyze uric acid levels. Data was analyzed by Pearson's test.

Reuslts : Most of subjects (94\%) had uric acid levels in the normal category. Total of 94\% subject purine intake was low, less than $500 \mathrm{mg}$ per day, 64\% of vitamin C intake subject was high, more than >60 mg per day and 53\% of physical activity subject was normal. There were a correlation positive between intake of purine, vitamin $C$ and physical activity and uric acid levels $(p=0,000)$.

Conclusion : There was significant correlation between intake of purin, vitamin $C$ and physical activity and uric acid levels.
\end{abstract}

Keyword : purine intake; vitamin C; physical activity; uric acid levels; boys adolescent

\section{ABSTRAK}

Latar Belakang : Hiperurisemia merupakan keadaan dimana kadar asam urat dalam darah di atas batas normal. Kadar asam urat dipengaruhi oleh asupan purin, vitamin $C$ dan aktivitas fisik.

Tujuan : Penelitian ini bertujuan untuk mengatahui hubungan asupan purin, vitamin $C$ dan aktivitas fisik terhadap kadar asam urat pada remaja laki-laki.

Metode : Jenis penelitian adalah observasional dengan rancangan cross-sectional. Jumlah subjek penelitian adalah 66 remaja laki-laki (usia 16-18 tahun) di SMA Negeri 2 Slawi. Subjek dipilih dengan simple random sampling. Data meliputi karakteristik subjek, asupan purin, vitamin $C$, aktivitas fisik, dan kadar asam urat. Asupan purin dan vitamin C diperoleh melalui wawancara langsung menggunakan Food Frequency Semi Quantitative, data aktivitas fisik diperoleh dari kuesioner aktivitas fisik selama 3 hari. Metode enzimatik PAP uricase digunakan untuk menganalisis kadar asam urat. Data dianalisis menggunakan uji Pearson.

Hasil : Kadar asam urat sebagian besar subjek (94\%) termasuk dalam kategori normal. Sebanyak 94\% asupan purin subjek rendah, yaitu < $500 \mathrm{mg}$ per hari, 64\% asupan vitamin C subjek tinggi yaitu >60 mg per hari dan 53\% subjek aktivitas fisik normal. Terdapat hubungan antara asupan purin, vitamin $C$ dan aktivitas fisik terhadap kadar asam urat $(p=0,000)$.

Simpulan : Terdapat hubungan bermakna antara asupan purin, vitamin $C$ dan aktivitas fisik terhadap kadar asam urat pada remaja laki-laki.

Kata kunci : asupan purin; vitamin C; aktivitas fisik; kadar asam urat; remaja laki-laki

\section{PENDAHULUAN}

Masa remaja merupakan masa perubahan atau masa peralihan masa anak-anak menuju masa dewasa, pada masa ini remaja mengalami serangkaian perubahan biologis, perubahan psikologis, dan perubahan psikososial. Serangkaian perubahan yang terjadi pada masa remaja cenderung menimbulkan berbagai pemasalahan. ${ }^{1}$ Salah satu permasalahan yaitu perubahan perilaku makan yang akan mempengaruhi status gizi dan kesehatan pada fase kehidupan selanjutnya. ${ }^{2}$
Perilaku makan yang tidak seimbang antara makanan yang dikonsumsi dengan kebutuhan pada remaja akan menimbulkan masalah gizi kurang atau masalah gizi lebih. Masalah gizi kurang pada remaja cenderung terjadi karena pola makan tidak menentu, perubahan psikososial dan kebutuhan gizi yang tinggi. ${ }^{1}$ Meningkatnya risiko kesehatan seperti obesitas, hipertensi dan sindrom metabolik pada masa remaja perlu perhatian khusus, dimana obesitas dan sindrom metabolik berkaitan dengan kejadian hiperurisemia. ${ }^{3,4}$ 
Hiperurisemia merupakan keadaan dimana kadar asam urat dalam darah di atas normal $\geq 7$ $\mathrm{mg} / \mathrm{dl}$ pada laki-laki dan $\geq 6 \mathrm{mg} / \mathrm{dl}$ pada perempuan. ${ }^{5}$ Di Indonesia prevalensi hiperurisemia masih belum diketahui pasti, tetapi penelitan yang dilakukan di Bandungan, Jawa Tengah atas kerjasama WHO-COPCORD terhadap 4.683 sampel menunjukan prevalensi kejadian hiperurisemia pada usia remaja, yaitu sebesar $0,8 \%$ yang meliputi pria $1,7 \%$ dan wanita $0,05 \% .^{6}$ Penelitian yang dilakukan di Korea antara tahun 2008 dan 2011 dengan 28.589 sampel menunjukan prevalensi hiperurisemia sebesar 13,8 \% yang meliputi 27,1 pada laki-laki dan $5,2 \%$ pada wanita. $^{7}$ Penelitian yang dilakukan di Jepang menunjukan sebanyak $20,7 \%$ remaja mengalami hiperurisemia dan kejadian ini dialami oleh remaja laki-laki. $^{3}$

Peningkatan kadar asam urat dapat dipengaruhi oleh berbagai faktor risiko yaitu jenis kelamin, umur, asupan tinggi purin, alkohol, obesitas, hipertensi, diabetes melitus, dan dislipidemia. ${ }^{8}$ Selain itu peningkatan kejadian asam urat berhubungan dengan gangguan fungsi ginjal. ${ }^{9}$ Prevalensi kejadian hiperurisemia lebih tinggi terjadi pada laki-laki, karena terjadinya hiperurisemia dipengaruhi oleh hormon estrogen, salah satu fungsinya adalah untuk mengekskresi asam urat dari dalam tubuh. Pada laki-laki tidak terdapat hormon estrogen yang tinggi sulit untuk mensekresi asam urat. ${ }^{10}$ Kadar asam urat pada lakilaki mulai meningkat setelah masa pubertas. ${ }^{5}$

Salah satu faktor yang dapat mempengaruhi kadar asam urat adalah makanan yang mengandung tinggi purin. ${ }^{7,10}$ Asupan purin tinggi apabila $\geq 1000 \mathrm{mg} /$ hari. $^{10}$ Penelitian sebelumnya menunjukan adanya peningkatan kadar asam urat ketika responden mengkonsumsi makanan sumber purin yang terdapat dalam daging dan seafood dalam jumlah banyak. Akan tetapi tidak ditemukan adanya peningkatan kadar asam urat ketika responden mengkonsumsi protein hewani dalam bentuk susu. ${ }^{11}$

Selain itu konsumsi makanan sumber vitamin C dapat meningkatkan ekskresi asam urat, sehingga mengurangi terbentuknya kristal urat. Vitamin $\mathrm{C}$ dapat menghambat reabsorpsi asam urat oleh ginjal, sehingga meningkatkan kecepatan kerja ginjal untuk mengekresikan asam urat melalui urin. Pada penelitian sebelumnya menunjukan bahwa asupan vitamin $\mathrm{C} \geq 500$ $\mathrm{mg} /$ hari dapat menurunkan konsentrasi serum asam uratbaik vitamin $\mathrm{C}$ yang berasal dari suplemen. ${ }^{12}$

Salah satu faktor yang dapat mempengaruhi kadar asam urat adalah aktivitas fisik. Aktivitas yang dilakukan oleh manusia berkaitan dengan kadar asam urat yang terdapat dalam darah. Aktivitas fisik seperti olahraga atau gerakan fisik akan menurunkan ekskresi asam urat dan meningkatkan produkasi asam laktat dalam tubuh. Semakin berat aktivitas fisik yang dilakukan dan berlangsung jangka panjang, maka semakin banyak asam laktat yang diproduksi. ${ }^{13}$

Berdasarkan uraian diatas, peneliti tertarik untuk mengetahui hubungan asupan purin, vitamin $\mathrm{C}$ dan aktivitas fisik terhadap kadar asam urat pada remaja laki-laki. Hasil penelitian ini diharapkan dapat memberikan informasi kepada masyarakat tentang ada atau tidak adanya hubungan asupan purin, vitamin $\mathrm{C}$ dan aktivitas fisik terhadap nilai kadar asam urat pada remaja laki-laki sehingga dapat mencegah risiko hiperurisemia sejak dini.

\section{METODE PENELITIAN}

Penelitian ini termasuk dalam ruang lingkup keilmuan gizi masyarakat dan merupakan penelitian observasional dengan menggunakan rancangan cross-sectional. Populasi target penelitian ini adalah remaja laki-laki berusia 1618 tahun di kecamatan slawi pada tahun 2014 dan populasi terjangkau pada penelitian ini adalah seluruh siswa laki-laki berusia 16-18 tahun di SMA Negeri 2 Slawi. Hasil skrining awal yang dilakukan pada 250 orang berasal dari siswa kelas XI dan XII. Besar sampel dalam penelitian ini adalah 66 orang. Subjek dipilih berdasarkan kriteria inklusi yaitu remaja laki-laki usia 16-18 tahun, bersedia menjadi sampel dengan mengisi informed consent, memiliki indeks masa tubuh berdasarkan umur $15-85^{\text {th }}$ persentil, memiliki lingkar pinggang $<90 \mathrm{~cm}$, tidak menderita penyakit atau dalam perawatan dokter berkaitan dengan penyakit hipertensi, gagal ginjal, jantung, diabetes dan penyakit kronik lainnya, tidak mengkonsumsi alkohol, serta tidak sedang mengkonsumsi suplemen, jamu dan obat-obatan penurun kadar asam urat. Kriteria eksklusi adalah subjek mengundurkan diri saat penelitian berlangsung. Variabel bebas dalam penelitian ini adalah asupan purin, asupan vitamin $\mathrm{C}$ dan aktivitas fisik. Variabel terikat adalah kadar asam urat.

Pengambilan data dilakukan pada bulan Agustus 2014. Data yang dikumpulkan dalam penelitian ini adalah karakteristik subjek, asupan purin, asupan vitamin $\mathrm{C}$ dan aktivitas fisik. Diawali dengan melakukan skrining terhadap siswa laki - laki yang berusia 16 - 18 tahun dengan pengukuran antropometri untuk menentukan status gizi dan pengisian kuesioner mengenai kriteria inklusi. Data status gizi 
diperoleh dari pengukuran antropometri berupa tinggi badan dengan menggunakan microtoise ketelitian $0,1 \mathrm{~cm}$, berat badan menggunakan timbangan injak digital dengan ketelitian $0,1 \mathrm{~kg}$ dan lingkar pinggang menggunakan alat pita ukur dengan ukuran maksimal $150 \mathrm{~cm}$. Subjek yang memiliki Indeks Massa Tubuh (IMT) berdasarkan umur $15-85^{\text {th }}$ persentil dan ukuran lingkar pinggang $<90 \mathrm{~cm}$ dikategorikan normal. Sebanyak 66 orang sesuai dengan kriteria inklusi diambil dengan cara simple random sampling.

Data asupan asupan purin dan vitamin C diperoleh melalui formulir Food Frequency Semi Quantitative dengan melakukan wawancara. Hasil yang diperoleh kemudian diolah menggunakan program nutrisurvey. Asupan purin dan vitamin C dihitung rerata konsumsi perhari. Hasil pengolahan data asupan purin dikategorikan menjadi rendah apabila asupan purin dibawah $500 \mathrm{mg}$ per hari, dikatakan normal apabila asupan purin dalam rentang 500-1000 mg per hari, dan berlebih apabila asupan purin diatas $1000 \mathrm{mg}$ per hari. Adapun angka kecukupan asupan vitamin $\mathrm{C}$ menurut $\mathrm{AKG}$ sebesar $60 \mathrm{mg}$ per hari dan dikatakan berlebih apabila diatas $60 \mathrm{mg}$ per hari. Data aktivitas fisik diperoleh dari kuesioner selama 3 hari (2 hari aktif dan 1 hari libur). Data yang diperoleh kemudian dihitung dengan mengalikan berat badan, koefisien aktivitas fisik dan menit yang digunakan hasilnya dibagi 3 untuk mendapatkan rata-rata pengeluaran energi satu hari. Hasil perhitungan aktivitas fisik dikategorikan menjadi aktivitas fisik ringan apabila nilainya dibawah 2000 kkal, aktivitas fisik sedang apabila nilainya rentang 2001-2400 kkal, dan aktivitas fisik berat apabila nilainya diatas 2401 kkal.
Kadar asam urat diperoleh dari pengambilan spesimen $3 \mathrm{cc}$ darah melalui vena cubiti mediana oleh analis laboratorium, kemudian sampel darah dimasukan ke dalam tabung yang selanjutnya disentrifus. Metode pengukuran kadar asam urat diukur dengan enzimatik kolorimetri yang menggunakan fotometer atau analyzer kimiawi. Kemudian hasilnya dikategorikan rendah sebesar $<3.4 \mathrm{mg} / \mathrm{dl}$, normal $3.4-7.0 \mathrm{mg} / \mathrm{dl}$, dan tinggi sebesar $>7.0 \mathrm{mg} / \mathrm{dl}$.

Data yang sudah diperoleh kemudian diolah dan dianalisis secara statistik menggunakan program komputer. Analisis deskriptif digunakan untuk melihat gambaran karakteristik subjek penelitian berupa asupan purin, asupan vitamin C, aktivitas fisik, dan nilai kadar asam urat. Data-data tersebut diuji normalitasnya menggunakan uji kolmogorof-smirnov dan analisis bivariat. ${ }^{14}$ Analisis bivariat dilakukan dengan uji $r$ pearson Test untuk mengetahui hubungan asupan purin, vitamin $\mathrm{C}$ dan aktivitas fisik terhadap kadar asam urat.

\section{HASIL PENELITIAN \\ Karaksteristik subjek}

Hasil skrining awal yang dilakukan pada 250 subjek siswa laki-laki dengan melakukan pengukuran tinggi badan, berat badan, dan lingkar pinggang. Pada skrining awal, diperoleh sebanyak 66 subjek dengan status gizi normal dilihat dari Indek Massa Tubuh (IMT) persentil berdasarkan umur sesuai dengan kreteria inklusi. Pada penelitian ini subjek berusia berkisar 16-18 tahun, sebagian besar subjek berusia 17 tahun sebanyak 31 subjek (47\%).

Tabel 1. Nilai Rerata berdasarkan usia, lingkar pinggang, indeks massa tubuh, asupan purin, asupan vitamin C, aktivitas fisik dan kadar asam urat

\begin{tabular}{lccc}
\hline \multicolumn{1}{c}{ Variabel } & Minimum & Maksimum & rerata \pm SD atau Median \\
\hline Usia (tahun) & 16 & 18 & $16.71 \pm 0.674(17)$ \\
Lingkar pinggang (cm) & 63.7 & 76.7 & $70.90 \pm 3.16(70.75)$ \\
Indeks Massa Tubuh (persentil) & 30 & 78.5 & $49.98 \pm 11.58(49.8)$ \\
Asupan Purin (mg) & 178.11 & 1015.70 & $365.23 \pm 136.66(352.6)$ \\
Asupan vitamin C (mg) & 39.2 & 124.7 & $68.45 \pm 18.97(72.25)$ \\
Aktivitas fisik (kkal) & 1779 & 2475 & $2025.88 \pm 147.02(20.3)$ \\
Kadar asam urat (mg/dl) & 3.6 & 7.8 & $5.82 \pm 0.955(5.9)$ \\
\hline
\end{tabular}

Berdasarkan pada Tabel 1, dalam penelitian rerata lingkar pinggang subjek $70.90 \pm 3.16 \mathrm{~cm}$ berkisar antara 63.7 sampai $76.7 \mathrm{~cm}$. Indeks Massa Tubuh (IMT) persentil berdasarkan umur subjek berkisar antara 30.0 sampai 78.5 persentil dengan rerata $49.98 \pm 11.58$ persentil. Asupan purin subjek berkisar antara 178.11 sampai $1015.170 \mathrm{mg}$ dengan rerata $365.23 \pm 136.66 \mathrm{mg}$. Asupan vitamin C subjek berkisar antara 39.2 sampai $124.7 \mathrm{mg}$ dengan rerata $68.45 \pm 18.97 \mathrm{mg}$. Rerata aktivitas fisik $2025.88 \pm 147.02 \mathrm{kkal}$ berkisar antara 1779 sampai 2475 kkal. Rerata Kadar asam urat subjek $5.82 \pm 0.955 \mathrm{mg} / \mathrm{dl}$ berkisar antara 3.6 sampai 7.8 $\mathrm{mg} / \mathrm{dl}$. Distribusi frekuensi subjek berdasarkan kategori variabel penelitian dapat dilihat pada tabel 2. 
Tabel 2. Distribusi frekuensi Asupan Purin, Asupan Vitamin C, Aktivitas Fisik dan Kadar Asam Urat Subjek

\begin{tabular}{llcc}
\hline Variabel & Kategori & n & Persen \% \\
\hline Asupan purin & $<500 \mathrm{mg}$ (rendah) & 62 & 94 \\
& $500-1000 \mathrm{mg}$ (normal) & 3 & 4.5 \\
& $>1000 \mathrm{mg}$ (tinggi) & 1 & 1.5 \\
\hline Asupan vitamin C & $\pm 60 \mathrm{mg}$ (cukup) & 24 & 36 \\
& $>60 \mathrm{mg}$ (tinggi) & 42 & 64 \\
\hline Aktivitas fisik & $<2000 \mathrm{kkal}$ (ringan) & 29 & 44 \\
& $2001-2400$ kkal (sedang) & 35 & 53 \\
& $>2401 \mathrm{kkal}$ (tinggi) & 2 & 3 \\
\hline Kadar asam urat & $<3.4 \mathrm{mg} / \mathrm{dl}$ (rendah) & 0 & 0 \\
& $3.4-7.0 \mathrm{mg} / \mathrm{dl}$ (normal) & 62 & 94 \\
& $>7.0 \mathrm{mg} / \mathrm{dl}$ (hiperurisemia) & 4 & 6 \\
\hline
\end{tabular}

Pada tabel 2 menunjukan bahwa sebesar $94 \%$ $(\mathrm{n}=62)$ subjek dalam kategori asupan purin rendah dibawah $500 \mathrm{mg}$ per hari, sebesar $4.5 \% \quad(\mathrm{n}=3)$ subjek dalam kategori normal antara 500 sampai $1000 \mathrm{mg}$ per hari dan sebesar $1.5 \%(\mathrm{n}=1)$ subjek memiliki asupan purin diatas $1000 \mathrm{mg}$ per hari. Nilai median asupan purin yaitu $352.63 \mathrm{mg}$ per hari.

Asupan Vitamin C sebesar 36\% ( $\mathrm{n}=24)$ subjek dalam kategori cukup berkisar dibawah $60 \mathrm{mg}$ per hari, dan sebesar $64 \% \quad(n=42)$ subjek dalam kategori asupan vitamin $\mathrm{C}$ diatas $60 \mathrm{mg}$ per hari. Nilai median asupan vitamin $\mathrm{C}$ yaitu $72.25 \mathrm{mg}$ per hari

Pada aktivitas fisik sebesar 44\%(n=29) subjek dalam kategori ringan dibawah <2000 kkal, sebesar 53\% ( $\mathrm{n}=35)$ subjek dalam kategori sedang berkisar 2001 sampai $2400 \mathrm{kkal}$ dan sebesar 3\% $(\mathrm{n}=2)$ subjek dalam kategori tinggi yaitu lebih dari 2400 kkal. Nilai median aktivitas fisik yaitu 2032 kkal.
Kadar asam urat sebesar 94\% ( $=62)$ subjek dalam kategori dengan kategori normal berkisar antara 3.4 sampai $7.0 \mathrm{mg} / \mathrm{dl}$ dan sebesar $6 \%(\mathrm{n}=4)$ dalam kategori kadar asam urat tinggi diatas 7.0 $\mathrm{mg} / \mathrm{dl}$. Nilai median kadar asam urat $5,95 \mathrm{mg} / \mathrm{dl}$.

Hubungan Asupan Purin, Vitamin C dan Aktivitas Fisik terhadap Kadar Asam Urat

Tabel 3 menunjukan hasil uji bivariat hubungan masing-masing variabel meliputi asupan purin, asupan vitamin $\mathrm{C}$ dan aktivitas fisik terhadap kadar asam urat. Berdasarkan hasil uji korelasi Pearson menunjukan bahwa asupan purin berhubungan bermakna dengan kadar asam urat $(\mathrm{p}=0,00)$ dan menunjukan arah korelasi positif $(\mathrm{r}=0.640)$. Asupan vitamin $\mathrm{C}$ dalam uji bivariat menunjukan bahwa asupan vitamin $\mathrm{C}$ berhubungan bermakna dengan kadar asam urat $(\mathrm{p}=0.00)$ dan menunjukan arah positif $(\mathrm{r}=0.606)$. Sedangkan pada aktivitas fisik dalam uji bivariat menunjukan berhubungan bermakna dengan kadar asam urat $(\mathrm{p}=0.00)$ dan berkolerasi positif $(\mathrm{r}=0.624)$.

Tabel 3. Hubungan asupan purin, vitamin $\mathrm{C}$ dan aktivitas fisik terhadap kadar asam urat

\begin{tabular}{lcc}
\hline \multicolumn{1}{c}{ Variabel } & \multicolumn{3}{c}{ Kadar Asam Urat } \\
\cline { 2 - 3 } & $\mathbf{r}$ & $\mathbf{p}$ \\
\hline Asupan Purin & 0.640 & 0.000 \\
Asupan Vitamin C & 0.606 & 0.000 \\
Aktivitas Fisik & 0.624 & 0.000 \\
\hline
\end{tabular}

Uji korelasi pearson

\section{PEMBAHASAN}

Hasil penelitian yang dilakukan pada 66 subjek remaja laki-laki yang berusia 16-18 tahun menunjukan sebagian besar kadar asam urat $94 \%$ subjek berada dalam kategori normal, yaitu antara 3.4 sampai $7.0 \mathrm{mg} / \mathrm{dl}$, sebesar $6 \%$ subjek kadar asam urat tinggi diatas $7.0 \mathrm{mg} / \mathrm{dl}$. Kadar asam urat dipengaruhi banyak faktor, salah satunya asupan purin, vitamin $\mathrm{C}$ dan aktivitas fisik. Pada penelitian ini menunjukan bahwa sebagian besar $94 \%$ subjek dalam kategori asupan purin rendah dibawah 500 mg per hari, sebanyak $4.5 \%$ subjek dalam kategori normal antara 500 sampai $1000 \mathrm{mg}$ per hari dan sebanyak $1.5 \%$ subjek memiliki asupan purin diatas $1000 \mathrm{mg}$ per hari. Asupan vitamin C sebanyak 36\% subjek dalam kategori cukup berkisar dibawah $60 \mathrm{mg}$ per hari, dan sebanyak $64 \%$ subjek dalam kategori asupan vitamin $\mathrm{C}$ diatas $60 \mathrm{mg}$ per hari. Pada aktivitas fisik sebanyak $44 \%$ subjek dalam kategori ringan dibawah <2000 kkal, sebanyak 53\% subjek dalam kategori sedang berkisar 2001 sampai $2400 \mathrm{kkal}$ dan sebanyak $3 \%$ subjek dalam kategori tinggi yaitu lebih dari 2400 kkal. 
Penelitian ini ditemukan hubungan bermakna antara asupan purin terhadap kadar asam urat pada remaja laki-laki. Purin merupakan senyawa basa organik yang menyusun asam nukleat dan termasuk dalam kelompok asam amino unsur pembentuk protein. ${ }^{15}$ Nukleotida terdiri atas nukleosida yang mengikat asam fosfat. Nukleotida dan fosfat menghidrolisis mononukleotida menjadi nukleotida sehingga bisa diserap atau diubah menjadi basa purin serta pirimidin. Proses pembentukan asam urat sebagian besar dari metabolisme nukleotida purin endogen, guanosine monophosphate (GMP), inosine monophosphate (IMP) dan adonosine monophosphate (AMP). Pembentukan asam urat dari nukleosida purin melalui basa purin hipoxantin, xantin, dan guanin dengan produk akhir asam urat. Sumber purin pada manusia ada tiga yaitu, dari makanan sumber purin (eksogen), degradasi asam nukleat menjadi nukleotida purin (endogen), dan sintesis de novo. ${ }^{16}$ Asupan purin subjek sebagian besar rendah kurang dari $500 \mathrm{mg} /$ hari. Asupan puin normalnya kurang dari $1000 \mathrm{mg} / \mathrm{hari}$. Sumber makanan yang mengandung purin, antara lain seperti seafood, daging, jerohan, kacang-kacangan biji kering. ${ }^{5}$

Pada asupan vitamin $\mathrm{C}$ ditemukan adanya hubungan bermakna antara asupan vitamin C terhadap kadar asam urat pada remaja laki-laki. Vitamin C merupakan mikronutrien yang berperan dalam berbagai reaksi enzimatik dan non enzimatik. Peningkatan konsentrasi vitamin C dapat menghambat reabsopsi asam urat. Vitamin $C$ memodulasi konsentrasi serum asam urat melalui efek uricosuriknya. Vitamin $\mathrm{C}$ dan asam urat diserap melalui pertukaran anion di tubulus proksimal ginjal. ${ }^{12}$ Penelitian sebelumnya yang dilakukan pada manusia dan hewan telah menunjukan bahwa pemberian vitamin $\mathrm{C}$ meningkatkan aliran plasma ginjal dan laju filtrasi glomerulus dan melemahkan peningkatan tekanan arteri. Vitamin $\mathrm{C}$ dapat mengurangi stres oksidatif dan peradangan karena itu menurunkan sintesis asam urat. ${ }^{17}$ Asupan vitamin C pada subjek penelitian sebagian besar tinggi sebesar lebih dari $60 \mathrm{mg}$ per hari. Asupan vitamin C normalnya \pm 60 $\mathrm{mg}$ per hari. ${ }^{18}$ Dalam penelitian ini terdapat hubungan bermakna positif, hal ini terjadi karena konsumsi asupan vitamin $\mathrm{C}$ subjek kurang dari 500 mg per hari dan sebagian besar subjek kadar asam urat dalam kategori normal. Meningkatnya ekskresi kadar asam urat tergantung pada jumlah vitamin $\mathrm{C}$ yang di konsumsi. Kelebihan vitamin $\mathrm{C}$ yang berasal dari makanan tidak menimbulkan gejala, tetapi konsumsi vitamin $\mathrm{C}$ berupa suplemen secara berlebihan setiap harinya dapat berisik gangguan pada ginjal. ${ }^{18}$ Sedangkan pada penelitian sebelumnya menyebutkan konsumsi vitamin $\mathrm{C}$ lebih dari $500 \mathrm{mg}$ per hari dalam bentuk suplemen selama 2 bulan dapat menurunkan kadar asam urat. $^{12}$

Hasil aktivitas fisik pada penelitian ini ditemukan adanya hubungan bermakna antara aktivitas fisik terhadap kadar asam urat pada remaja laki-laki. Penelitian yang dilakukan pada laki-laki menjelaskan bahwa aktivitas fisik yang berat dapat mempengaruhi kadar asam urat. Pada saat seseorang melakukan aktivitas fisik yang berat, seseorang akan mengalami dehidrasi yang diakibatkan karena kelelahan. Kondisi dehidrasi dapat mempengaruhi dari volume urin karena eksresi dari asam urat menurun. ${ }^{19}$

Pada aktivitas yang bersifat anaerobik, energi yang akan digunakan oleh tubuh untuk melakukan aktivitas yang membutuhkan energi secara cepat ini akan diperoleh melalui hidrolisis phosphocreatine ( $\mathrm{PCr}$ ) serta melalui glikolisis glukosa secara anaerobik. Proses metabolisme energi secara anaerobik ini dapat berjalan tanpa kehadiran oksigen $\left(\mathrm{O}_{2}\right)$. Proses glikolisis yang terjadi di dalam sitoplasma sel akan mengubah molekul glukosa menjadi asam piruvat dimana proses ini juga akan disertai dengan pembentukan ATP. Molekul asam piruvat yang terbentuk dari proses glikolisis dapat mengalami proses metabolisme lanjut baik secara aerobik maupun secara anaerobik tergantung pada ketersediaan oksigen di dalam tubuh. Pada saat berolahraga dengan intensitas rendah dimana ketersediaan oksigen di dalam tubuh cukup besar, molekul asam piruvat yang terbentuk ini dapat diubah menjadi $\mathrm{CO}_{2}$ dan $\mathrm{H}_{2} \mathrm{O}$ di dalam mitokondria sel. Jika ketersediaan oksigen terbatas di dalam tubuh atau saat pembentukan asam piruvat terjadi secara cepat, maka asam piruvat tersebut akan terkonversi menjadi asam laktat. Dalam penelitian tersebut seseorang yang melekukan aktivitas berat ditemukan kadar asam urat tinggi. Aktivitas fisik yang berat juga akan meningkatkan akumulasi asam laktat darah, hal ini menyebabkan retensi asam urat dalam darah terjadi. Namun, dalam penelitian tersebut belum bisa menjelaskan secara pasti tentang mekanisme asam laktat yang mempengaruhi asam urat. ${ }^{19,20}$

\section{SIMPULAN}

Hasil penelitian menunjukan sebagian besar subjek memiliki kadar asam urat normal berkisar antara 3.4 sampai $7.0 \mathrm{mg} / \mathrm{dl}$, yaitu $94 \%$ dan sebesar $6 \%$ subjek memiliki kadar asam urat tinggi diatas $7.0 \mathrm{mg} / \mathrm{dl}$. Asupan purin sebagian besar subjek 
rendah kurang dari $500 \mathrm{mg} / \mathrm{hari}$ yaitu $94 \%$, sebesar $4.5 \%$ subjek memiliki asupan purin normal dan sebesar $1.5 \%$ subjek memiliki asupan purin diatas $1000 \mathrm{mg} /$ hari. Asupan vitamin C subjek sebagian besar lebih $60 \mathrm{mg} / \mathrm{hari}$ yaitu $64 \%$ dan asupan vitamin $\mathrm{C}$ subjek kurang dari $60 \mathrm{mg} /$ hari yaitu $36 \%$. Aktivitas fisik subjek sebagian besar sedang berkisar antara 2001-2400 kkal yaitu 53\%, subjek memiliki aktivitas ringan kurang dari $2000 \mathrm{kkal}$ yaitu $44 \%$ dan sebesar $3 \%$ subjek memiliki aktivitas tinggi. Pada penelitian ini asupan purin, vitamin $\mathrm{C}$ dan aktivitas fisik pada remaja laki-laki berhubungan terhadap kadar asam urat dengan arah korelasi positif.

\section{SARAN}

Kadar asam urat yang tinggi pada masa remaja dapat meningkatkan risiko berbagai penyakit yang berpotensi berkembang pada masa selanjutnya. Sebagai upaya pencegahan penyakit yang berhubungan dengan kadar asam urat sebaiknya menghindari konsumsi makanan yang mengandung tinggi purin, konsumsi vitamin $\mathrm{C}$ sesuai kebutuhan dan membatasi aktivitas fisik yang berlebih dengan intensitas lama.

\section{DAFTAR PUSTAKA}

1. Khomsan A. Pangan dan gizi untuk kesehatan. Jakarta: Grafindo Persada; 2003. p56-9.

2. Arisman MB. Gizi dalam daur kehidupan. Jakarta : Penerbit Buku Kedokteran. EGC; 2002. p62-71.

3. Tang Li, Kubota M, Nagai A, Mamemoto K, Tokuda M. 2010. Hyperuricemia in obese children and adolescents: the relationship with metabolic syndrome. Japan : Department of Human Life and Environment, Nara Women's University. NutritionResearch 2010; 2: 12.

4. Jen YW, Yen LC, Chun HH, Sai HT, Chung ZW, Dee P.Predictive Value of Serum Uric Acid Levels for the Diagnosis of Metabolic Syndrome in Adolescents. J Pediatr 2012; 161:753-6.

5. Isselbacher. Harrison Prinsip-prinsip ilmu penyakit dalam. Asdie HA, editor Vol 5. Ed 13. Jakarta: Penerbit Buku Kedokteran EGP. 2000. p2301-05.

6. Darmawan J, Valkenburg HA, Muiden KD, Wigley RD. The epidemiology of gout and hyperuricemia in arural population of Java. $\mathbf{J}$ Rhematol 1992; 19: p1595-9.

7. Kyoung AR, Hyun HK, So Y K, Min KY,Jeong SK, Chan HL, Gyung AW, et al. Comparison of nutrient intake and diet quality between hyperuricemia subjects and controls in Korea. Clin Nutr 2014; 3: 56-63.

8. Luk AJ, Simkin PA. Epidemiology of hyperuricemia and gout. The American Journal of Managed Care 2005: 11: 435 442.

9. Wibowo, Kaparang AM, Moeis ES, Kapajos AL. Renal fuction in Minahasanese patient with chronic gout arthritis antophi. Acta Med Indones 2005: 37(2): 61-65.

10. Nelms M, Sucher KP, Lacey K, Roth SR. Nutrition therapy and pathophysiology. $2^{\text {nd }}$ edition. United State: Cengange; 2010. p793.

11. Choi HK, Simin L, Gary C. Intake of purinerich foods, protein and dairy products and relationship to serum levels of uric acid. The Third National Health and Nutrition Examination Survey (Arthritis \& Rheumatism). 2005;52(1): 283-289.

12. Huang HY, Appel LJ, Choi MJ, et al. The effects of vitamin $\mathrm{C}$ supplementations on serum consentrations of uric acid. Arthritis Rheum 2005; 52: 1843-7.

13. Rodwell VW. Metabolisme nukleotida purin dan pirimidin. In : Bani Anna P Sikumbang Tiara MN (Ed): Biokimia Harper. Jakarta : EGC ; 2003. P.366,374-376.

14. Dahlan MS. Statistik untuk Kedokteran dan Kesehatan. Jakarta : Salemba Medika ; 2008.p.31-57, 170-174.

15. Poedjiadi A. Dasar-dasar biokimia. Jakarta: UI-Press;1994. p126-39.

16. Rodwell VW. Harper's illustrated biochemistry $27^{\text {th }}$ edition. Singapore: McGraw Hill; 2006. p311-317

17. Niu T, Kristina DT, Paul DG, Michel DH, R Davis M. Antioxidant treatment prevent renal demage and dysfunction and reduse arterial, pressure in salt sensitive hypertension. American Health Assosiation Inc. 2005; 45:934-939.

18. Almatsier S. Prinsip dasar ilmu gizi. Jakarta: Gramedia; 2003. 185-190.

19. Quick AJ. The effect of exercise on the excretion of uric acid. J. Biol. Chem 1935, 110:107-112.

20. Fross ML, Keteyen SJ. Physiological basis for Exercise and sport. New York: Mc Graw Hill; 2006. P59-64. 